\title{
ANALISA DAN PERANCANGAN SISTEM INFORMASI PENGADAAN BAHAN BAKU PADA PT. XYZ
}

\author{
Atikah \\ Program Studi Teknik Informatika, Universitas Indraprasta PGRI \\ Email: atikahmardi1@gmail.com
}

\begin{abstract}
Abstrak
PT. XYZ adalah perusahaan yang bergerak dibidang linen yang menspesialisasikan diri pada produk damask dan towel. PT. XYZ merupakan perusahaan tekstil terpadu yang terdiri dari pemintalan (spining), penenunan (weaving), pencelupan (dyeing) dan konveksi. PT. XYZ melakukan operasional yang berbeda dengan perusahaan tekstil lainnya, baik dalam proses produksi, desain, dan memasarkan produknya ke masyarakat luas, dimana PT. XYZ menerima pesanan dari costumer yang mencakup desain serta macam barang yang dipesan dan tidak memasarkannya ke masyarakat luas (go public). Dalam melakukan kegiatan produksinya sangat berkaitan dengan persediaan bahan baku yang merupakan komponen penting yang harus tersedia untuk kelancaran proses produksi. Persediaan dalam suatu unit usaha dapat dikategorikan sebagai modal kerja yang berbentuk barang. Keberadaannya di satu sisi dianggap sebagai pemborosan, tetapi di sisi lain juga dianggap sebagai asset yang sangat diperlukan untuk menjamin kelancaran pemenuhan permintaan. PT. XYZ belum memiliki sistem komputerisasi yang dapat menunjang kebutuhan pengadaan bahan baku untuk meningkatkan efisiensi dan efektifitas perusahaan khususnya pada bagian pengadaan bahan baku. Penelitian ini dilakukan dengan field research dan observation melalui tahapan perencanaan, analisis, desain. Penelitian ini dilakukan dengan tujuan untuk menghasilkan model perencanaan persediaan bahan baku, serta membantu PT. XYZ untuk memecahkan permasalahan yang dihadapi di divisi Purchasing, sehingga dapat dibentuk sistem yang lebih efisien.
\end{abstract}

Kata Kunci: Sistem Informasi, Analisis dan perancangan sistem,Pengadaan bahan baku.

\section{Pendahuluan}

Pesatnya perkembangan bisnis dalam segala bidang akhir-akhir ini menuntut adanya penyesuaian didalam penyajian informasi untuk kebutuhan para pengambil keputusan dan diperlukan pengembangan sebuah sistem. Ini dapat diartikan menyusun suatu sistem baru atau mengganti sistem yang lama secara keseluruhan atau bertahap, atau memperbaiki sistem yang sudah ada. PT. XYZ didirikan pada tahun 1983 untuk memenuhi permintaan dari operasi group hotel dan mengekspor dari kelompok hotel lainnya serta ditributor dari seluruh dunia. Dalam memenuhi pesanan permintaan yang semakin bertambah dari ekspor dan pasar lokal, PT. XYZ telah memiliki mesin tambahan dan meningkatkan pusat desain untuk memenuhi standar global yang dibutuhkan oleh pelanggan.

Pada proses kerjanya perusahaan menuntut agar hasil produksinya bisa menjamin suatu produk yang bermutu. Salah satu prosedur dalam pelaksanaan kerjanya adalah pada bagian Purchasing. Bagian ini memiliki peranan penting karena kulitas produk yang dihasilkan bergantung kepada bahan baku yang dibeli, kecepatan proses, pendataan atau pengarsipan yang baik juga ketepatan dalam penyajian laporan. Namun terjadi kesenjangan antara tuntutan perusahaan dan proses kerja di lapangan. Pada bagian ini sebagian besar pekerjaan dilakukan secara manual. Sehingga dalam penyajian informasi yang dibutuhkan terasa lama dan merepotkan.

Mendasari hal itu, untuk menyelesaikan permasalahan yang ada maka penulis melakukan penelitian analisa dan perancangan sistem informasi pengadaan bahan baku dengan tujuan Membantu PT. XYZ untuk memecahkan permasalahan yang dihadapi dibidang pengendalian persediaan bahan baku, sehingga dapat dirancang sistem yang lebih efisien. Penelitian ini dibatasi pada kegiatan dalam memproses permintaan akan kebutuhan bahan baku berupa 
negosiasi harga, menganalisa tawaran harga dari pemasok, menentukan pilihan, memilih pemasok, mengeluarkan perintah purchase order, menangani masalah dengan pemasok (retur bahan baku yang rusak atau tidak sesuai dengan bahan baku yang dipesan), serta menyimpan rekaman informasi yang diperlukan.

\section{Tinjauan Pustaka}

Definisi umum untuk 'informasi' dalam pemakaian Sistem Informasi adalah sebagai berikut ; informasi adalah data yang telah diolah menjadi sebuah bentuk yang berarti bagi penerimanya dan bermanfaat dalam mengambil keputusan, saat ini atau mendatang. Sistem Informasi didefinisikan oleh Robert A. Leitch dan K. Roscoe Davis sebagai berikut : Sistem Informasi adalah suatu sistem dalam suatu organisasi yang mempertemukan kebutuhan pengolahan transakasi harian, mendukung operasi, bersifat manajerial dan kegiatan strategi dari suatu organisasi dan menyediakan pihak luar tertentu dengan laporan-laporan yang diperlukan.

Sedangkan menurut (Sutono, 2007) Sistem Informasi adalah suatu sistem berbasis komputer yang menyediakan informasi bagi beberapa pemakai dengan kebutuhan yang serupa. Para pengguna sistem informasi biasanya tergabung dalam suatu entitas organisasi formal. Sistem infromasi memuat berbagai informasi penting mengenai orang, tempat, dan segala sesuatu yang ada di dalam atau di lingkungan sekitar organisai. Sistem informasi mengandung tiga aktivitas dasar di dalamnya, yaitu aktivitas masukan (input), pemrosesan (processing), dan keluaran (output). Sistem informasi dapat didefinisikan sebagai suatu komponen yang saling berhubungan yang mengumpulkan, memproses, menyimpan, dan mendistribusikan informasi untuk mendukung pengambilan keputusan dan kendali dalam suatu organisasi (Sidh, 2013). Sistem informasi dapat meminimalisir kehilangan data dan kesalahan manusia, yang sering terjadi karena pemrosesan dan penyimpanan transaksi data yang dilakukan secara manual.

Sistem informasi dapat memudahkan pengguna dalam melakukan operasi persediaan barang dan produksi dan memiliki pembagian tipe user yang ada berdasarkan hak akses masingmasing, user tersebut yaitu Admin, Gudang, Finansial, dan Manajer. Dengan adanya pembagian hak akses setiap user pada sistem tersebut, ditujukan agar tidak semua user dapat melakukan olah data pada sistem, dan menghindari kecurangan dalam input data dalam proses pemesanan, pembelian dan pemasukan barang. Sistem ini dapat menampilkan semua data barang, dapat menampilkan bukti penerimaan dan pengeluaran barang beserta biaya yang dikeluarkan dalam setiap transaksi produksi (Cahyana et al., 2012).

Sistem informasi manajemen sangat bergantung dari komponen-komponen dalam menghasilkan sistem informasi yang sesuai dengan kebutuhannya. Kesenjangan yang terjadi dalam pelaksanaan komponen tersebut akan menghasilkan informasi yang kurang akurat, kurang detail, kurang tepat waktu, dan kurang relevan yang nantinya akan mengakibatkan kesalahan dalam pengambilan keputusan pada perusahaan atau organisasi (Sidh, 2013). Terdapat dua alasan utama mengapa terdapat perhatian yang besar terhadap manajemen informasi, yaitu meningkatnya kompleksitas kegiatan organisasi tata kelola pemerintahan dan meningkatnya kemampuan komputer. Selanjutnya, dengan tersedianya informasi yang berkualitas, tentunya juga mendorong manajer untuk meningkatkan kemampuan kompetitif (competitive advantage) organisasi yang dikelolanya.

Ekspektasi kinerja, ekspektasi usaha dan kondisi yang memfasilitasi berpengaruh positif secara signifikan terhadap minat pemanfaatan sistem informasi, sedangkan faktor sosial dan kesesuaian tugas tidak berpengaruh secara signifikan terhadap minat pemanfaatan sistem informasi (Ellyana et al., 2009).

Perancangan sistem informasi manajemen persediaan sangat perlu dilakukan agar tidak terjadi kekurangan barang yang terdapat digudang karena dengan adanya perancangan sistem informasi ini bagian bagian pusat dapat mengetahui secara langsung jumlah persediaan yang 
terdapat pada masing-masing gudang, kapan barang-barang tersebut harus dipesan, dan berapa banyak jumlah barang yang harus dipesan sehingga pemesanan barang dapat langsung dilakukan tanpa menunggu adanya permintaan barang oleh gudang-gudang cabang (Meilani \& Miftahudin).

Penelitian terkait yaitu program sistem informasi manajemen pengendalian persediaan bahan baku pada suatu perusahaan salah satunya persediaan bahan perpipaan pada satuan kerja pengembangan kinerja pengelolaan air minum dapat mempermudah pengolahan data pengendalian persediaan bahan, sehingga waktu yang dibutuhkan didalam pemrosesan data semakin cepat dan biaya yang dikeluarkan semakin kecil (Aldrin et al., 2013).

\section{Metodologi Penelitian}

Penelitian ini dilakukan di PT. XYZ, perusahaan yang bergerak di industri tektil berada di Cimanggis Depok. Pengumpulan data dilakukan dengan (field Research) yaitu dengan mengumpulkan data secara langsung melalui wawancara/interview, dan pengumpulan data berdasarkan pengamatan secara langsung (observasi) terhadap objek fisik berupa kegiatan yang sedang berlangsung dengan tahapan perencanaan, analisis, dan desain.Metode pendekatan sistem yang digunakan dalam penelitian ini menggunakan metode pendekatan terstruktur. Adapun alat bantu yang digunakan dalam metode terstruktur ini berupa diagram alir (flow map), diagram konteks dan data flow diagram sebagai alat bantu perancangan proses. Kamus data, tabel relasi, ERD (Entity Relationship Diagram) dan normalisasi sebagai alat bantu perancangan basis data. Perancangan input, perancangan output, pengkodean, struktur menu dan kebutuhan sistem sebagai alat bantu perancangan perangkat lunak.Metode pengembangan sistem yang digunakan dalam penelitian ini menggunakan model prototype. Prosesnya dimulai dengan mengumpulkan kebutuhan pengguna terhadap perangkat lunak kemudian dibuat perangkat lunak prototype. Perangkat lunak ini merupakan program aplikasi yang belum selesai dan akan terus dievaluasi oleh pengguna dan pengembang sampai memenuhi kebutuhan fungsional pengguna terhadap perangkat lunak.

\section{Hasil dan Pembahasan}

\section{Analisa Sistem Berjalan}

Prosedur proses sistem yang berjalan pada pengadaan bahan baku PT. XYZ adalah sebagai berikut:

1. Prosedur seleksi pemasok

Seleksi pemasok dilakukan dengan mengirimkan inquiry, yaitu surat permintaan penawaran harga terhadap kebutuhan bahan baku yang diminta oleh bagian Gudang. Setelah mengirimkan inquiry, biasanya pemasok akan mengirimkan surat penawaran harga. Purchasing akan menyeleksi pemasok mana yang menawarkan harga yang rendah tapi dengan kualitas barang yang sama bagusnya.

2. Prosedur pemesanan barang

Gudang meminta pengadaan bahan baku ke Purchasing dengan memberikan form material requirement. Purchasing memeriksa form material requirement tersebut dan memasukkan datanya kedalam arsip material requirement. Setelah itu, purchasing membuat surat pesanan yang datanya berasal dari arsip material requirement. Data yang diambil hanya nama barang dan jumlah barang yang dibutuhkan. Setelah surat pesanan selesai dibuat, maka Purchasing mengirimkan surat pesanan yang telah dibuat ke Supplier.

3. Prosedur Pembuatan Tanda Terima

Tanda terima dibuat setelah barang yang dibeli telah dikirimkan oleh Supplier dan diterima oleh Gudang. Tanda terima dibuat berdasarkan data yang ada dalam tanda terima barang, faktur, dan faktur pajak standar. Ketiga data ini berasal dari Gudang. Selanjutnya, ketiga data tersebut dimasukkan dalam filling cabinet. Dalam pembuatan tanda terima, hanya data tertentu saja yang diambil. Dari form faktur pajak standar data 
yang diambil hanya data nomor. Dari form faktur hanya data tanggal dan faktur yang diambil. Dari form tanda terima barang data yang diambil adalah data tanda terima barang serta nomor tanda terima barang. Selanjutnya, tanda terima yang telah dibuat dikirimkan ke Supplier.

4. Prosedur Pembuatan Laporan

Pembuatan laporan meliputi laporan material requirement dan laporan surat pesanan. Kedua laporan ini dilaporkan setiap bulan dan diserahkan kepada manajer Personalia dan Purchasing.

Ketentuan / Aturan

1. Jika ingin melakukan Purchase Order sumber data harus berasal dari MaterialRequirement yang telah disetujui oleh pimpinan yang terkait.

2. Bagian purchasing membuat dua laporan yaitu laporan Purchase order dan laporan material requirement.

3. Laporan dibuat dalam periode satu bulan dan diserahkan setiap akhir bulan kepada manager personalia dan purchasing.

4. Proses pembelian bahan baku dilaksanahan dalam kurun waktu sebulan sebelum bahan baku tersebut digunakan.

\section{Diagram Alir Data Sistem Berjalan}

Adapun diagram alir data sistem berjalan sebagai berikut:

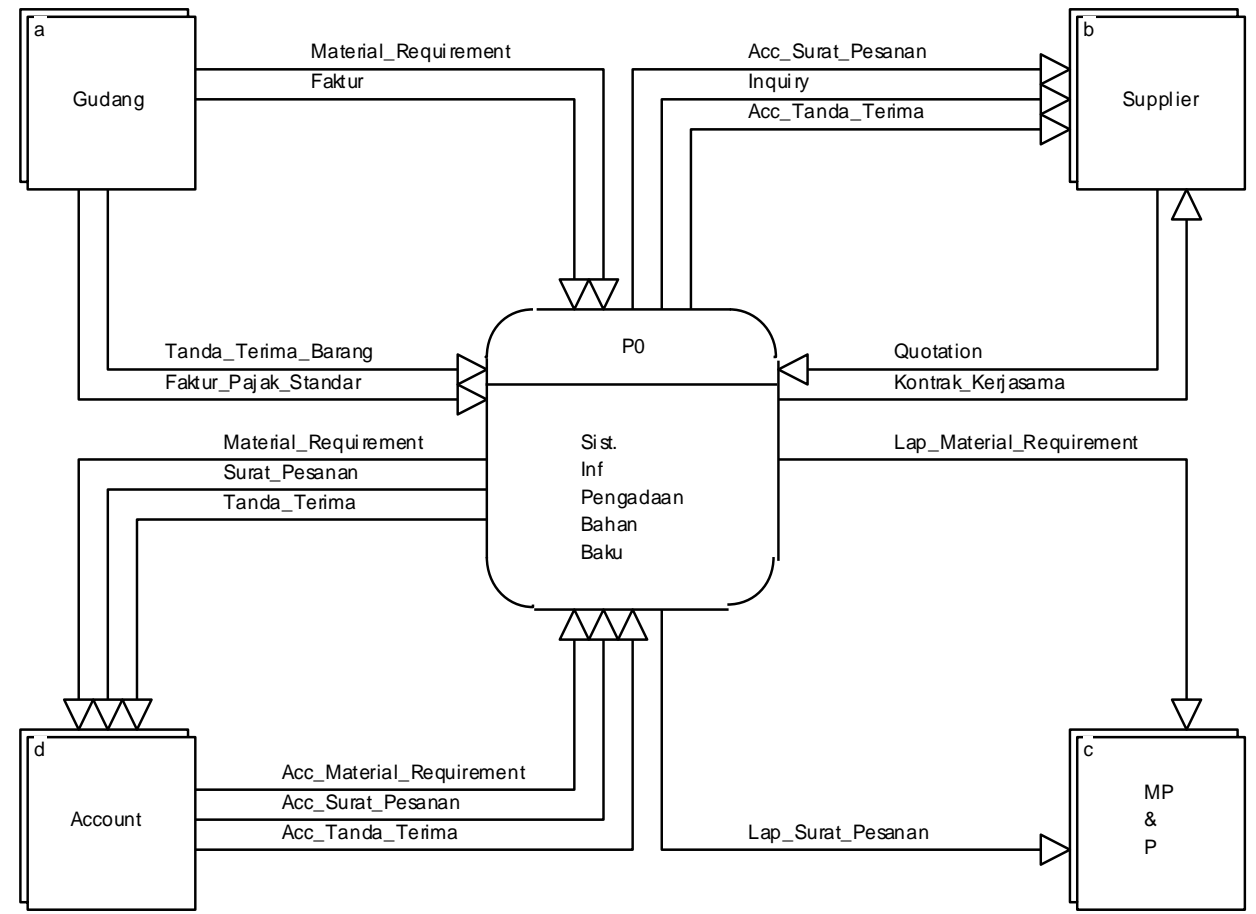

Gambar 1. Diagram Konteks Sistem Berjalan 


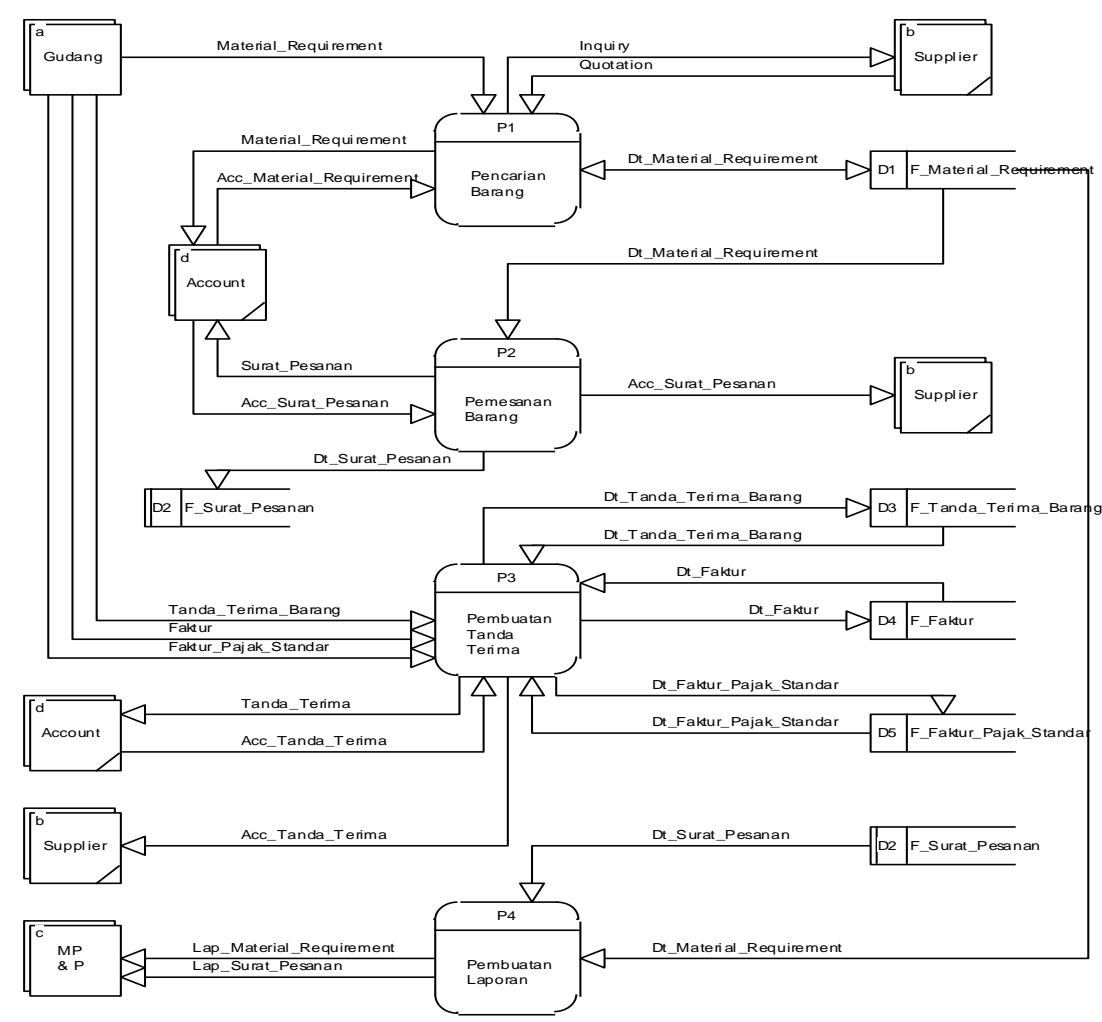

Gambar 2. Diagram Nol Sistem Berjalan

\section{Perancangan Sistem Usulan}

1. Prosedur perekaman data awal

Prosedur ini dilakukan dengan merekam data yang akan digunakan sebagai masukan pada sistem usulan seperti, data material requirement serta data bahan baku.

2. Prosedur seleksi Supplier

Seleksi pemasok dilakukan dengan mengirimkan inquiry, yaitu surat permintaan penawaran harga terhadap kebutuhan bahan baku yang diminta oleh bagian gudang. Setelah mengirimkan inquiry, biasanya pemasok akan mengirimkan quotation.Purchasing akan meneyeleksi pemasok mana yang menawarkan harga yang rendah dengan kualitas barang yang sama bagusnya.

3. Prosedur pemesanan bahan baku

Manajer Finance \& Account melakukan permintaan bahan baku ke bagian Purchasing dengan memberikan form material requirement. Purchasing memeriksa form material requirement tersebut dan merekam datanya di file material requirement. Kemudian, purchasing menghubungi pihak Supplier untuk meminta data bahan baku beserta rincian harganya serta melakukan tawar menawar harga. Setelah harga yang ditawarkan cocok maka bagian Purchasing meminta persetujuan dari Manajer Personalia \&Purchasing. Setelah itu, Purchasing membuat form Purchase Order yang datanya berasal dari form material requirement. Data yang diambil hanya data nama bahan baku yang diperlukan dan jumlah barang yang dibutuhkan. Setelah itu, Purchasing mengirimkan Purchase Order ke Supplier.

4. Prosedur penerimaan bahan baku

Prosedur penerimaan bahan baku dilakukan pada saat bagian Purchasing menerima barang yang telah dipesan dari Supplier. Bagian Purchasing memeriksa barang yang diterima dengan melihat surat jalan, apakah barang yang dikirimkan sesuai dengan jenis dan jumlah bahan baku yang dipesan. Supplier juga mengirimkan faktur dan faktur pajak standar terhadap barang yang di pesan. Setelah itu, urchasing mengirimkan barang ke 
Gudang dengan disertai form tanda terima bahan baku yang nantinya akan diisi oleh Gudang. Tetapi jika ada bahan baku yang tidak sesuai dengan pesanan atau ada bahan baku yang rusak maka Purchasing akan menghubungi pihak Supplier, kemudian Purchasing akan membuat form returbahan baku.

5. Prosedur pembuatan laporan

Pembuatan laporan terbagi menjadi 6 macam yaitu pembuatan laporan material requirement per no. MR, laporan material requirement per tanggal, laporan purchase order per no. PO, laporan purchase order per tanggal dan laporan retur bahan baku per no. retur, laporan retur bahan baku per Supplier. Laporan ini dilaporkan setiap satu bulan dan diserahkan ke Manajer Personalia dan Purchasing.

Ketentuan/aturan:

1. Pemilihan Supplier didasarkan kepada hasil seleksi yang dilakukan bagian Purchasing dengan mempertimbangkan penawaran harga yang ditawarkan dari pihak Supplier.

2. Proses pemesanan barang dilakukan setelah terjadi kesepakatan harga antara pihak Purchasing dengan Supplier.

3. Penerimaan bahan baku telah sah dilakukan jika barang yang dikirim sesuai dengan deskripsi yang tertera dalam faktur pengiriman barang dari Supplier.

4. Jika terjadi retur, maka pihak Purchasing sebagai pemesan barang akan menghubungi pihak Supplier dengan menyertakan info retur yang berisikan deskripsi barang yang rusak beserta keterangan kerusakan yang terjadi pada barang yang bersangkutan.

5. Dalam hal pelaporan dilakukan secara berkala tiap 1 bulan.

\section{Diagram Alir Data Sistem Berjalan}

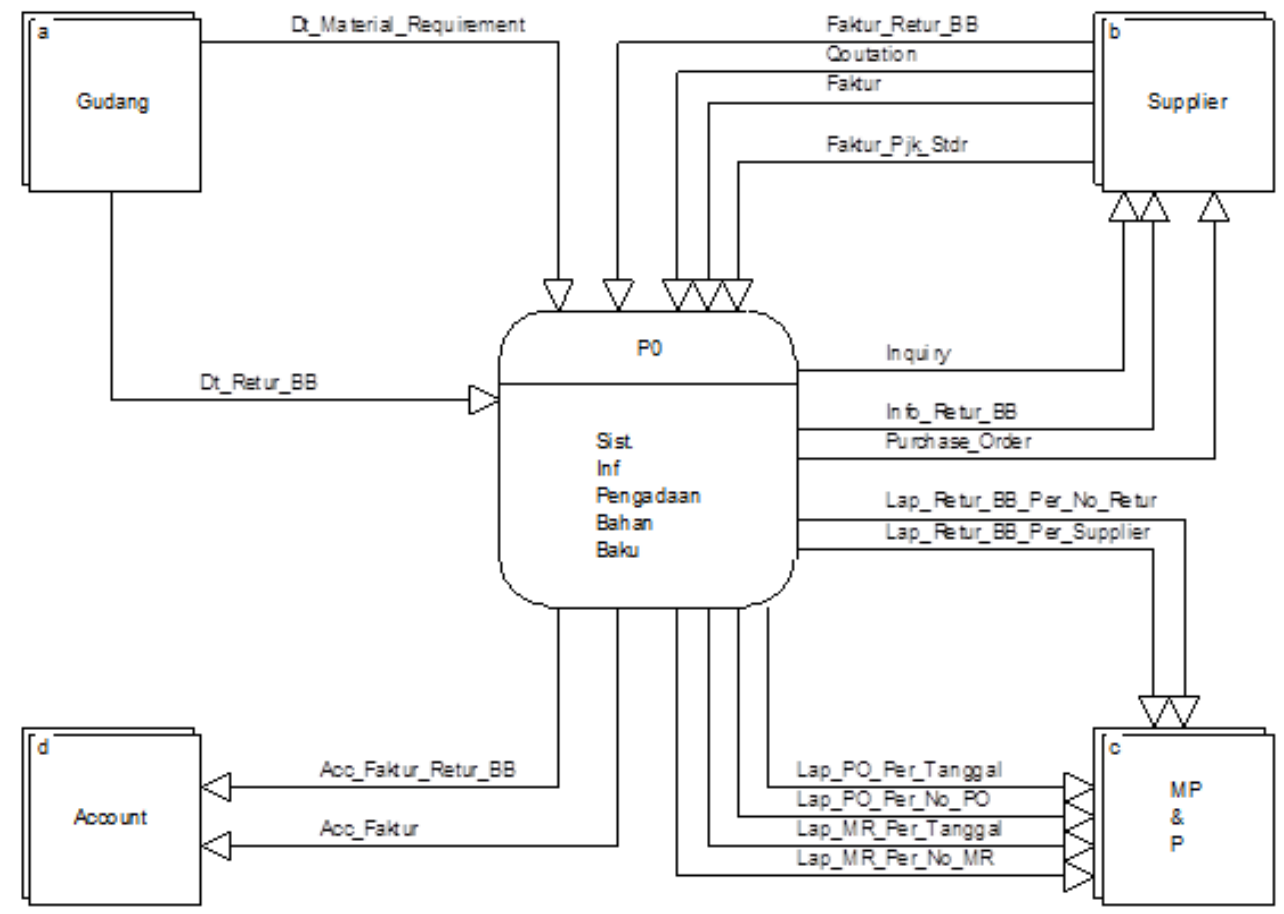

Gambar 3. Diagram Konteks Sistem Usulan 


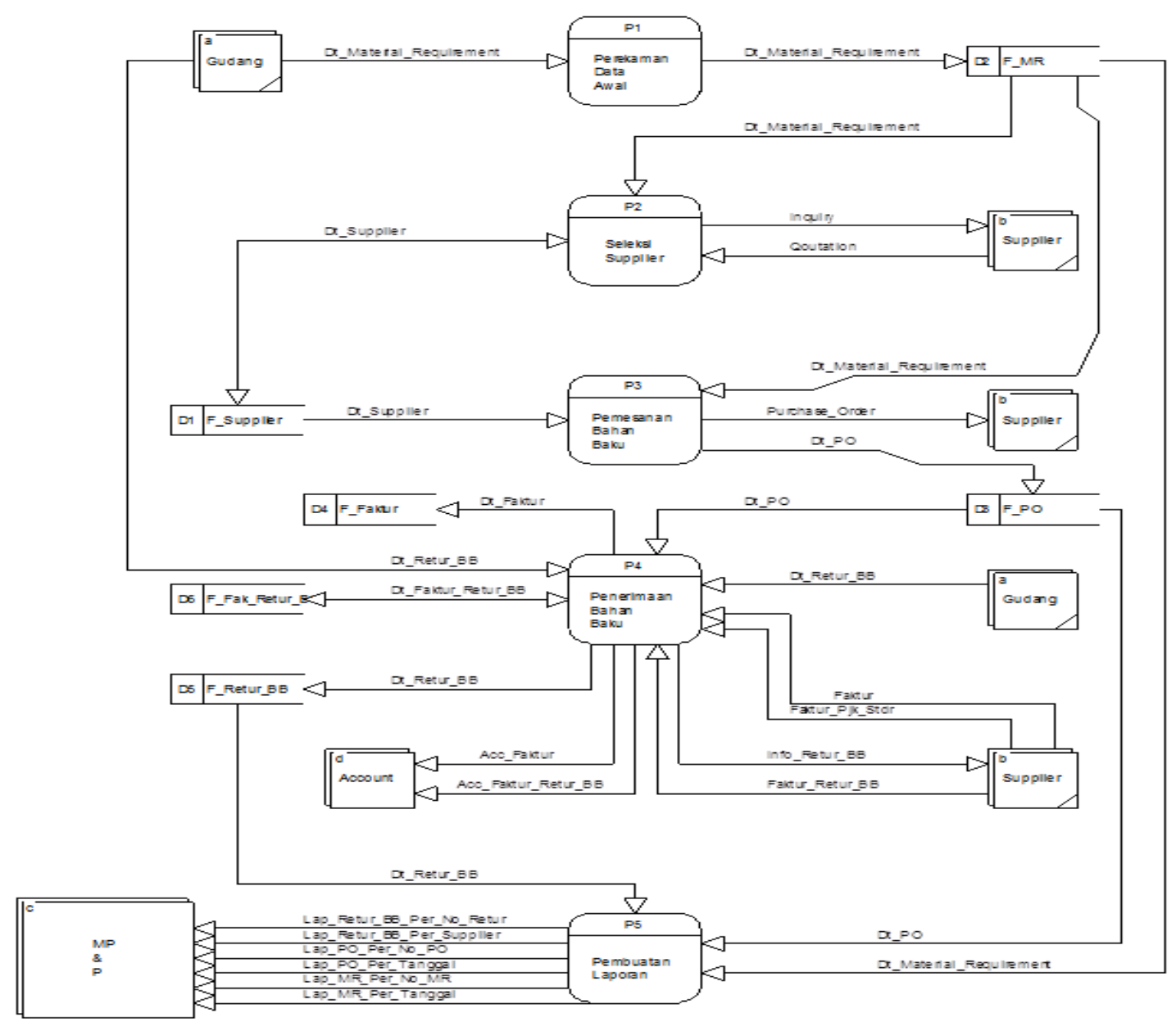

Gambar 4. Diagram Nol Sistem Usulan

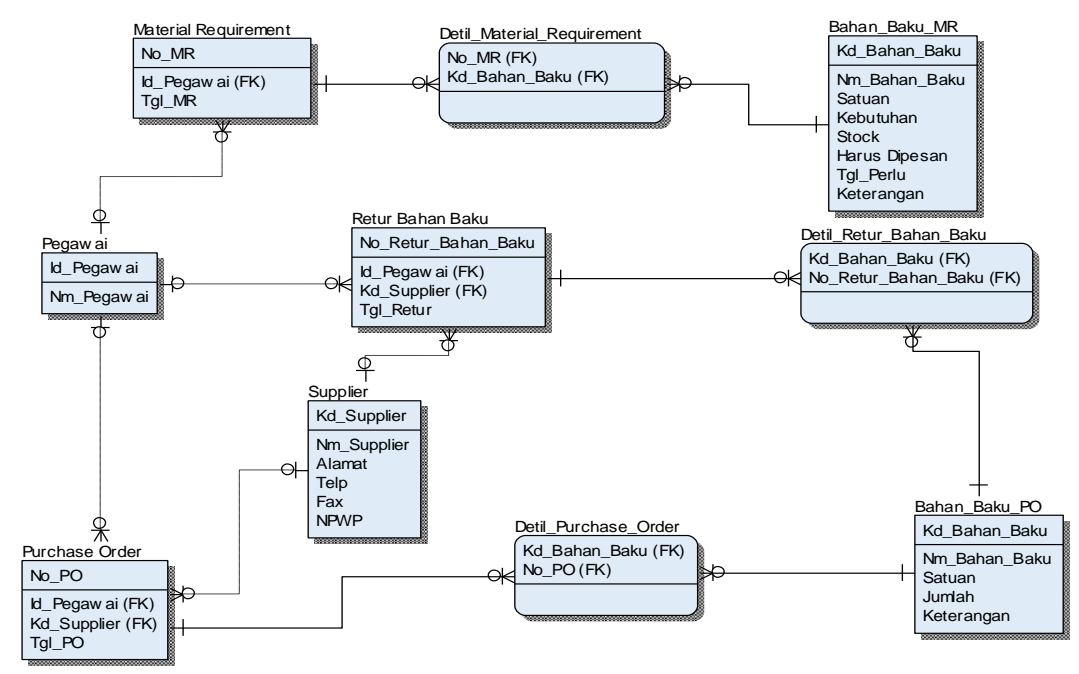

Gambar 5. Diagram Hubungan Entitas (ERD)

Spesifikasi Sistem Usulan 


\section{Bagan Pengolahan Terstruktur}

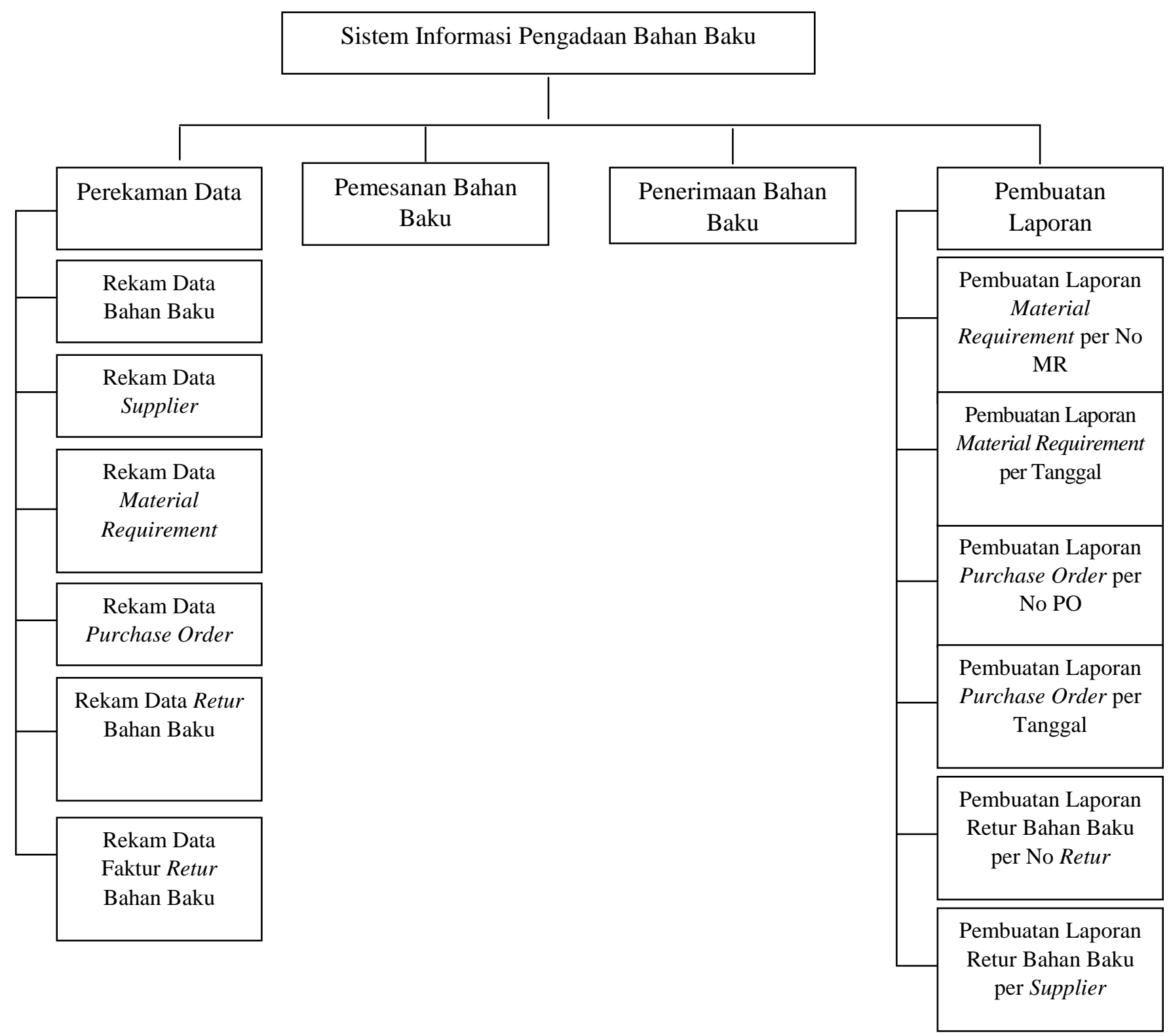

Gambar 6. Bagan Pengolahan Terstruktur

\section{Rancangan Struktur Menu Pengoperasian}

Perancangan program ini dibagi menurut tiap bagian. Sebab tidak semua bagian bisa mengakses program pada bagian lain. Tiap bagian telah dibuat modul program yang mendukung pekerjaan yang dilakukan. 


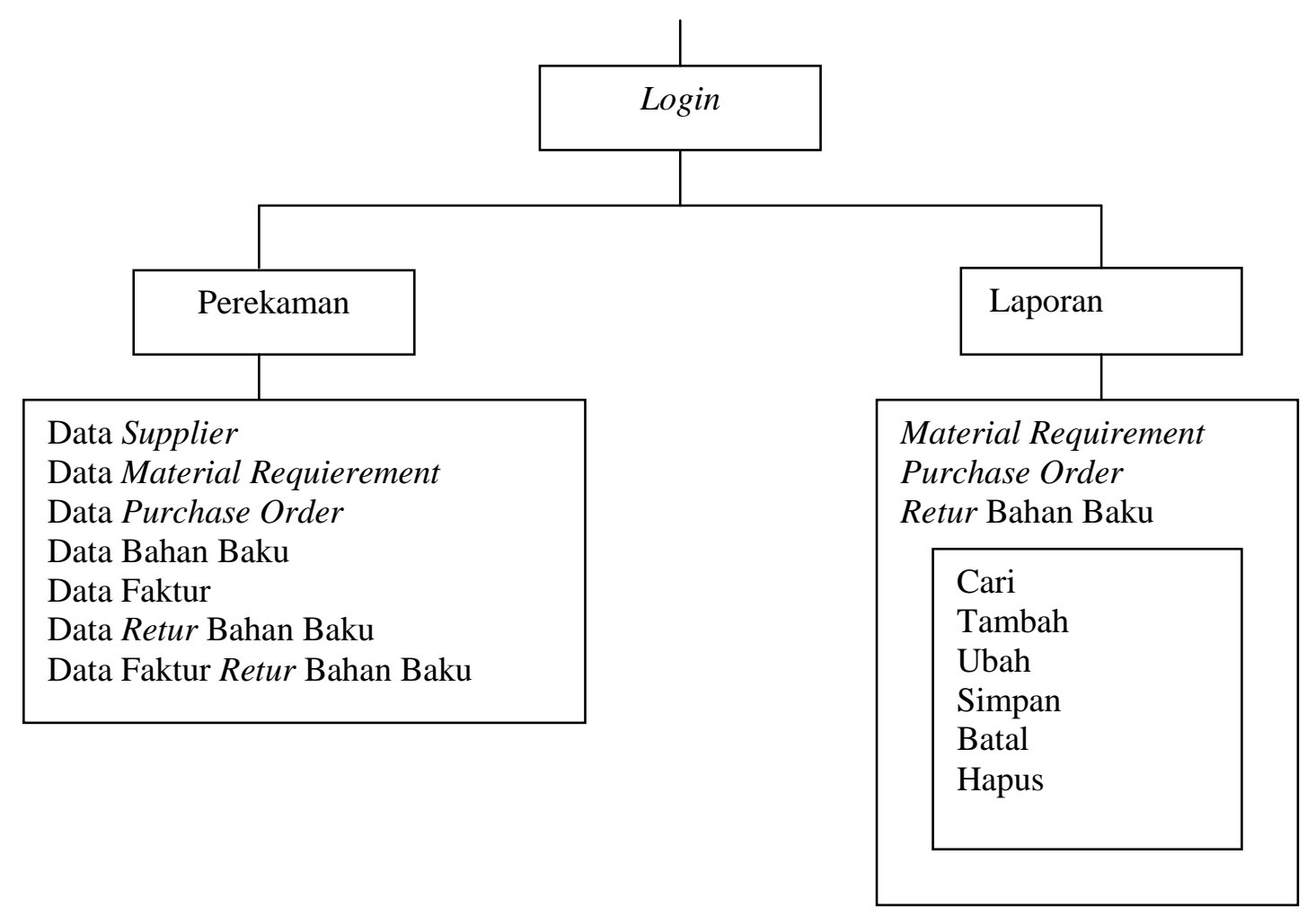

\section{Gambar 7. Struktur Menu Pengoperasian}

\section{Keamanan Sistem}

Untuk menghindari kerusakan data atau untuk menghindari pemakaian sistem tanpa persetujuan, perlu diadakan suatu keamanan komputer yang bertujuan untuk melindungi data dan membatasi penggunaan sistem. Keamanan komputer terdiri dari 2 macam, yaitu pengamanan piranti keras dan pengamanan piranti lunak:

Bentuk keamanan komputer terdiri dari:

1. Backup data dilakukan secara periodik (setiap hari) untuk menghindari hilangnya data karena kerusakan hard disk.

2. Penggunaan Uninterruptable Power Supply (UPS) untuk mencegah rusaknya sistem atau hilangnya informasi karena gangguan listrik.

3. Mekanisme pengendalian akses (acces control) terbagi 2 yaitu:

a. Kontrol akses fisik bertujuan untuk mencegah seseorang untuk mendapatkan akses fisik ke dalam sistem dengan menggunakan gembok, penjaga, tanda pengenal, dan tanda-tanda administrasi serupa.

b. Kontrol akses logik bertujuan untuk mencegah seseorang melakukan eksploitasi terhadap akses fisik ke dalam sistem dengan informasi dan pengetahuan (User-ID dan Password)

\section{Konfigurasi Sistem}

Didalam membangun dan menerapkan sistem komputerisasi selalu dikaitkan dengan peralatan pendukung di dalam pelaksanaan suatu pekerjaan. Peralatan pendukung ini adalah perangkat keras dan perangkat lunak. Peralatan tersebut di bagi dalam beberapa kelompok sesuai dengan fungsinya yaitu sebagai peralatan masukkan, peralatan pengolahan data, 
peralatan keluaran yang akan dipakai sebagai alat proses dan penyimpanan data sehingga menghasilkan informasi yang dibutuhkan.

1. Perangkat Keras Server

Tabel 1. Spesifikasi Server

\begin{tabular}{lll}
\hline No & Nama & Keterangan \\
\hline 1 & Processor & Dual Xeon \\
2 & Memori & 2 GB RAM \\
3 & Hard Disk & 40 GB \\
4 & Floopy Disk & $1,44 \mathrm{MB}$ \\
5 & CD ROM & DVD RW \\
6 & Monitor & 15 Inchi SVGA \\
7 & Kartu Jaringan & 56 Kbbps \\
8 & Keyboard & PS2 \\
9 & Mouse & PS2 \\
10 & UPS & Min 1 KVA \\
11 & Printer & Laset Jet \\
\hline
\end{tabular}

2. Perangkat Keras Client

Tabel 2. Spesifikasi Client

\begin{tabular}{lll}
\hline No & Nama & Keterangan \\
\hline 1 & Processor & Dual Core 2 Ghz \\
2 & Memori & 1 GB RAM \\
3 & Hard Disk & 20 GB \\
4 & Floopy Disk & $1,44 \mathrm{MB}$ \\
5 & CD ROM & DVD RW \\
6 & Monitor & 15 Inchi SVGA \\
7 & Kartu Jaringan & 56 Kbbps \\
8 & Keyboard & PS2 \\
9 & Mouse & PS2 \\
10 & Printer & Bubble Jet \\
\hline
\end{tabular}

3. Spesifikasi Perangkat Lunak Komputer

Setelah melakukan pemilihan perangkat keras komputer sistem usulan, langkah selanjutnya adalah menentukan perangkat lunak komputer guna mengoperasikan sistemnya.

Tabel 3. Spesifikasi Software Server

\begin{tabular}{ll}
\hline Software & Spesifikasi \\
\hline Sistem Operasi & Windows 2003 Server \\
Aplikasi & Visual Basic 6.0 \\
Database & Microsoft Access \\
\hline
\end{tabular}

Tabel 4. Spesifikasi Software Client

\begin{tabular}{ll}
\hline Software & Spesifikasi \\
\hline Sistem Operasi & Windows 2000/XP Professional \\
Aplikasi & Visual Basic 6.0 \\
Office & Office 2007 \\
Antivirus & Norton Antivirus \\
\hline
\end{tabular}

4. Topologi Jaringan

Topologi jaringan yang penulis usulkan untuk PT. XYZ adalah menggunakan topologi Star. Salah satu sentral dibuat sebagai sentral pusat. Sistem ini mempunyai tingkat kerumitan jaringan yang lebih sederhana sehingga sistem menjadi lebih ekonomis, tetapi beban yang dipikul di sentral pusat cukup berat. 


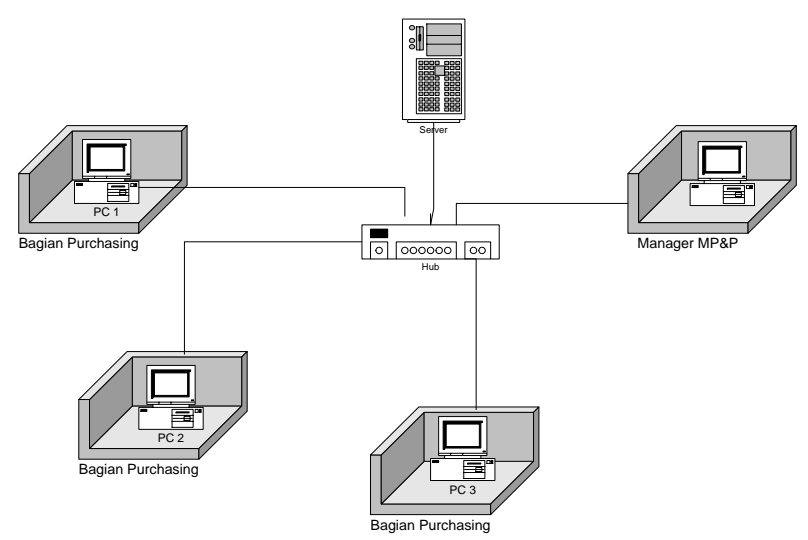

Gambar 8. Konfigurasi Jaringan Sistem Usulan

\section{Simpulan dan Saran}

Dari analisa sistem yang berjalan pada sistem pengadaan bahan baku pada PT. XYZ dapat disimpulkan bahwa sistem yang berjalan masih bersifat manual dan tidak saling terhubung sehingga dalam penyajian informasi sering terjadi keterlambatan. Tidak adanya keterkaitan antara bagian yang saling terhubung sehingga setiap bagian harus menunggu informasi dari bagian yang lain. Hal ini tentu akan menjadi suatu masalah yang besar jika tidak segera diatasi. Jika informasi yang dihasilkan tidak cepat, maka bisa dipastikan semua kegiatan yang ada pada PT. XYZ akan terganggu. Dengan terganggunya kegiatan berarti kegiatan produksi juga akan terganggu.

Untuk mengatasi masalah tersebut maka peneliti mencoba memberikan alternatif pemecahan masalah dengan pemanfaatan sistem jaringan dimana setiap bagian dapat saling terhubung. Ini berarti informasi akan cepat didapat serta diolah oleh bagian yang terkait. Dalam mendukung terlaksananya sistem informasi pengadaan bahan baku dengan jaringan, penulis memberikan saran perlu adanya integrasi sistem. Untuk pengoperasiannya diperlukan pengumpulan data awal untuk perekaman. Sistem ini membutuhkan server, yaitu bagian yang dapat mengontrol sistem jaringan secara umum. Pada pengembangan selanjutnya, penulis menyarankan agar selalu dilakukan pemeliharaan (maintenance) sistem agar dapat mendukung kinerja dari sistem.

\section{Daftar Pustaka}

Aldrin, T., Sompie, B.F., Rantung, J.P. (2013). Sistem informasi manajemen pengendalian persediaan bahan instalasi perpipaan pada satuan kerja pengembangan kinerja pengelolaan air minum. Jurnal Ilmiah Media Engineering, Vol.3 No.2: 120-125.

Cahyana ,N.H., Yuwono, B., Asmoro, A.Y. (2012). Pengembangan system informasi persediaan barang berbasis WEB di PT. Putera Agung Setia. Seminar Nasional Informatika. Yogyakarta. 30 juni 2012.

Ellyana, D.D., Redy, A., Hamzah, A. (2009). Variabel antiseden dan konsekuensi pemanfaatan system informasi (studi empiris pada pemerintah kabupaten di Pulau Madura. Jurnal Akuntansi dan Keuangan Indonesia, Vol. 6 No.1.

Meliani, D., Miftahuddin. (2011). Perancangan Sistem Informasi Manajemen Persediaan (Studi Kasus : PDAM Tirta Sakti Kabupaten Kerinci). Jurnal Ilmiah Teknik Industri.

Sutono, D. (2007). Sistem Informasi Manajamen (Edisi ke-empat). Bogor : Pusat Pendidikan dan Pelatihan Pengawasan BPKP.

Sidh, R. (2013). Peranan Brainware Dalam Sistem Informasi Manajemen. Jurnal Computech \& Bisnis, 7(1): 19-29. 